\author{
St ud i P hilos o p hic a \\ Wr a t is l a vie n s i a \\ vol. XIV, fasc. 4 (2019) \\ DOI: $10.19195 / 1895-8001.14 .4 .6$
}

DANIEL KOMARZYCA

ORCID: 0000-0002-1562-994X

University of Wrocław

\title{
The Tao of Ethics and Politics: A Radical Reading of Taoist Philosophy
}

\begin{abstract}
The paper explores the possibility of finding radical elements of individualistic and libertarian (especially left-libertarian) thought in Taoist philosophy. It demonstrates that philosophical Taoism should be treated in a comprehensive way, with a particular emphasis on ethics. In connection with this, the anti-authoritarian ethico-political dimension of early Taoism is examined, and it is argued that the Taoist philosophers of ancient China had a deep respect for the equal liberty of individuals, who are all unique by nature. As a result, findings suggest that Taoist anarchism in early medieval China evolved as the logical conclusion from ancient Taoist ethico-political thought since radical ideas were embodied in it. The research goal of this paper is to develop a Taoist-libertarian virtue ethics and to show its political relevance. Therefore, it is also intended to show how Taoist libertarianism (avant la lettre) undermines political authority despite being neither consequentialist nor deontological, unlike typical American libertarianism.
\end{abstract}

Keywords: politics, Daoism, virtue, libertarianism, individualism, Zhuangzi

\section{Introduction}

This paper provides an investigation of coherent, radical socio-political and ethico-political ideas presented by Taoist (Daoist) philosophers (with particular emphasis on Zhuangzi). By taking an interdisciplinary approach, my analysis will be based on appropriate Taoist (Chinese to English professional translations) and scientific writings of both Western and Chinese scholars, most of them being philosophers (others specialising in sinology, political science, social psychology, and 
economics). Throughout this paper, "radical" and "radicalism" are understood as (1) views different in fundamental ways from the traditional ones. Furthermore, radical views (2) favour thorough or complete changes in existing value systems and/or social structures. Therefore, since radicalism is derived from the Latin radix (meaning "root"), it can be summed up as the "change at the root."

At the outset, it should be kept in mind that Chinese characters will be romanized in accordance with Hanyu Pinyin (with the exception of $\mathrm{TaO}^{1}$ and $\mathrm{Te}$ ) without using tone marks. By and large, the most important concepts in Taoism are: Tao (Dao 道) (a kind of universal principle, the formless source of the universe and the ground of the universe which flows through all things; it is noteworthy that Tao is simultaneously both transcendent and immanent ${ }^{2}$ ), Te ( $D e$ 德) (often translated as "inherent character" or "inner power," it is the manifestation and appearance of Tao in all beings, it is the Power embodied variously in individuals ${ }^{3}$ ), wu wei (無為) (non-coercive action ${ }^{4}$ and "acting with an empty heart-mind"5), pu (樸) (literally "unworked wood," it refers to the original simplicity), and ziran (自然) (naturalness, being free, spontaneously; literally "so of itself," 6 which could serve as a metaphor for human freedom in nature ${ }^{7}$ ).

Politically and historically, it is generally believed that philosophical/classical Taoism, which emerged as the source of all Taoist traditions, ${ }^{8}$ is the most anti-authoritarian Asian school of thought, whose reputed founder was Laozi (also known as Lao Tzu, literally "Old Master"). One can argue that original Taoist views on society, economy, politics, and ethics were fundamentally different from those favourable to the elites because early Taoists were nonconformists who criticized social oppression, and the political aspects of their philosophy were clearly visible. But are there really individualistic, consistently pro-liberty, and egalitarian-i.e. anti-authoritarian, left-libertarian ${ }^{9}$-ideas present in ancient Taoist texts? I will argue that the answer is yes, and so my thesis is that Taoism supports libertarian ethics. In order to prove such Chinese radicalism, before summing up ethics and focusing solely on politics, I will: (1) demonstrate the presence of individualism in early Taoism as it is necessary for individual liberty; (2) challenge the views of

1 This is why I use "Taoist" and not "Daoist."

${ }^{2}$ X. Liu, "Daoism: Laozi and Zhuangzi," [in:] The Oxford Handbook of World Philosophy, W. Edelglass, J. Garfield (eds.), Oxford 2011, pp. 48-49.

${ }^{3}$ Ibid., p. 48.

${ }^{4}$ E. Nelson, "Responding with 'dao': Early Daoist Ethics and the Environment," Philosophy East and West 59 (2009), p. 304.

${ }^{5}$ J. Iwanowska, "Can a Daoist Sage Have Close Relationships with Other Human Beings?," Diametros-An Online Journal of Philosophy 52 (2017), p. 43.

${ }^{6}$ See X. Liu, op. cit., pp. $49-50$.

7 J. Rapp, Daoism and Anarchism: Critiques of State Autonomy in Ancient and Modern China, New York 2012, pp. 31, 91-93.

${ }^{8}$ For the discussion of Taoism as a religion, see L. Kohn, Taoizm. Wprowadzenie [Introducing Daoism], transl. J. Hunia, Kraków 2012. Cf. J. Rapp, op. cit., pp. 8-10.

${ }^{9}$ Left-libertarianism is understood here broadly to include not just contemporary academic philosophers such as Hillel Steiner, Peter Vallentyne, and Michael Otsuka (the "Steiner-Vallentyne school"), but also anarchist thinkers (mutualists, agorists, etc.) and other libertarian socialists - according to the common political usage of the word. 
those who see this philosophy as being amoral, altruistic, or utilitarian ${ }^{10}$; and (3) show the Taoist anti-authoritarian moral attitudes expressed in the condemnation of imposing ways of life, harming, and people. In connection with this, it is essential to recognize that cross-cultural comparative philosophy is possible, as was demonstrated by Feng Youlan and Yong Huang. ${ }^{11}$

\section{Individualism in the Social Philosophy of Taoism}

There are two fundamental questions which should be raised here: (1) Did Taoists believe in individual agency? (2) What was the relationship between the individual and the group in Taoist texts? Nevertheless, in order to fully understand the answers, some other Taoist views need to be outlined first.

It is essential to understand that the polarities of yin and yang are not good and evil. ${ }^{12}$ What is good is a natural tendency towards balance and harmony between yin and yang (Tao). What is bad is human interference with the above-mentioned constant process and its homeostatic mechanisms. ${ }^{13}$ This is the reason why Taoist sages avoid excesses and extravagances. ${ }^{14}$ For instance, Laozi practised moderation and advised leaders to be more yin (to be softer, more feminine, like water) ${ }^{15}$ in order to counterbalance yang, which predominates in a patriarchal society. As a result, it has been claimed that the Taoist philosophy of Laozi is favourable to egalitarian feminist goals. ${ }^{16}$

10 These views were advocated, respectively, by Herlee G. Creel, Russell Kirkland, and Raymond Smullyan.

${ }^{11}$ See Y. Feng, Krótka historia filozofi chińskiej [A short history of Chinese philosophy], transl. M. Zagrodzki, Warszawa 2001, pp. 32-33; Y. Huang, "How to Do Chinese Philosophy in a Western Philosophical Context: Introducing a Unique Approach to Chinese Philosophy," Hanxue Yanjiu (Chinese Studies) 31 (2013), pp. 117-151.

12 The root cause of serious misconceptions regarding yin and yang may be the Western formal dualism (for an explanation of this term, see D. Sepczyńska, Libertarianizm. Mało znane dzieje pojęcia zakończone próbą definicji, Olsztyn 2013, pp. 123-124), which is based on restrictive binary logic.

According to Taoism, yin and yang coexist in nature (yin / nighttime / femininity / soft / cold / wet, etc.-yang / daytime / masculinity / hard / hot / dry, etc.) and they are equally valuable, interdependent, complementary, interconnected, interrelated, and inseparable (see, for example, M. Puett, Ch. Gross-Loh, The Path: What Chinese Philosophers Can Teach Us About the Good Life, New York 2017, pp. 144-145; Y. Feng, op. cit., p. 159), as opposed to the Western dichotomy between mind and body, spirit and flesh, head and heart, light and darkness, spiritual and profane, etc. Yin and yang are aspects of oneness, they are not antagonistic. Since they need each other to exist, extreme yang naturally transforms into yin and extreme yin naturally transforms into yang although this process may take some time. Furthermore, the yin-yang balance is not simply an average in statistics and these two poles represent what is natural (such balance should not be applied to anything unnatural).

13 Jung H. Lee interpreted early Taoist ethics as an ethics of attunement to the Way (Tao).

${ }^{14}$ Laozi, Tao Teh Ching, transl. J.C.H. Wu, New York 1961, https://terebess.hu/english/tao/ wu.html (accessed: 19.06.2019), Chapter 29; Laozi, Tao Te Ching, transl. W.-T. Chan, https://terebess.hu/english/tao/chan.html (accessed: 19.06.2019), Chapter 29 ("the sage discards the extremes, the extravagant, and the excessive").

15 See Daodejing, Chapters 6, 8, 10, 28, 36, 43, 61, 76, 78.

${ }^{16}$ See K. Lai, "The 'Daodejing': Resources for Contemporary Feminist Thinking," Journal of Chinese Philosophy 27 (2000), pp. 131-153. 
In Taoist terms, normally, everything has an inner dynamic and develops through a kind of spontaneous cooperation. In contrast, Westerners tend to look for a single cause, isolate every object they focus on from its background, and emphasize competition. ${ }^{17}$ Nevertheless, within Western psychology there is also, for instance, Taoist-influenced process-oriented psychology. ${ }^{18}$ All in all, for Taoists, process is more important than goal, becoming is more important than gaining, and "to be" is more important than "to have." Their social philosophy was inspired by all these concepts.

Although Taoists advised people to relax and follow the natural rhythm of life, it should not be forgotten that they also advised each person to be morally courageous and think for oneself. In modern times, some Eastern governments claim that traditional "Asian values" are different from "Western values" (mainly individual liberty), and such claim is designed to serve as the justification for authoritarianism in Asia. ${ }^{19}$ This is the reason why the existence of proto-libertarian philosophies in early China should be examined.

According to Zhuangzi ("Master Zhuang," also known as Chuang Tzu or Zhuang Zhou) - the most influential Taoist philosopher (along with Laozi), who lived around the 4th century BC-we should discover from within and accept ourselves together with our uniqueness $(T e)$, even under social pressure, because "if a man thus becomes someone else instead of himself, this is a fatal error [...]." ${ }^{\prime 20}$ Master Zhuang was aware of the different needs and preferences of individuals living in the world of plurality and multiplicity (wan wu; literally "the myriad creatures"). The philosopher often used the following ancient words to express the notion of "individual": " $j i$ 己" and " $d u$ 獨." ${ }^{\prime 21}$ It is noteworthy that he prized the uniqueness of each independent person in a similar manner to Henry David Thoreau. ${ }^{22}$ Taoists are not meddling thinkers as they do not force anyone to interact with others, especially if it goes against one's natural desires or inclinations; therefore, it is possible to be moral and, for example, live alone in the woods. These philosophers were against group tyranny and rejected the view that a group is the standard of moral value, thereby opposing vertical collectivism and emphasizing the moral worth of the individual instead (individualism).

${ }^{17}$ See R. Nisbett, The Geography of Thought: How Asians and Westerners Think Differently... and Why, New York 2003.

${ }^{18}$ I owe knowledge of this fact to Wioletta Aumer.

${ }^{19}$ This was particularly championed by Lee Kuan Yew (the former prime minister of Singapore).

${ }^{20}$ Zhuangzi, Chuang Tzu, transl. H. Giles, [sine loco] 2013, p. 96. Cf. Zhuangzi, The Complete Works of Chuang Tzu, transl. B. Watson, New York 1968, https://terebess.hu/english/chuangtzu.html (accessed: 19.06.2019), Chapter 8 ("if he finds joy in what brings joy to other men, but finds no joy in what would bring joy to himself, then [...] he is [...] deluded and perverse").

${ }^{21} \mathrm{~K}$. Xu, "A Different Type of Individualism in 'Zhuangzi,", Dao: A Journal of Comparative Philosophy 10 (2011), p. 448. For example: "In the text of the Zhuangzi the character of ' $d u$ 獨' (with the meanings of 'lonely,' 'alone,' 'sole,' 'unique,' or 'independent') was frequently used to indicate an independent and integrated personality, or the ideal status of individual spirit, which was advocated by Zhuangzi. [...] All of these emphasize the uniqueness of an individual that Zhuangzi admires and values highly. This is obviously relevant to the concept of individual and individualism" (ibid.). See also Y. Zhao, "Yang Zhu's 'Guiji' Yangsheng and Its Modern Relevance," Philosophy Study 4 (2014), pp. 175-176; for example: “'ji' is merely an independent private entity separated from others or relationships [...]" (p. 176).

${ }^{22}$ See K. Xu, op. cit., pp. 448, 450. 
A recent piece of cross-cultural research by Erica Brindley has revealed that individualism is not exclusively Western as it was also present in ancient Taoist texts. However, Chinese individualism is, to some degree, different from Western (often possessive or atomistic) individualism. Hence, Taoist individualism is holistic (in the sense of environmental holism and not the social one), and the self is conceived as dynamic and embodied. ${ }^{23}$ From the Taoist (including Laozian) point of view, since "the distinctiveness of particular individuals [Te] is valued, then unilateral or reductive norms which obliterate such individuality are inappropriate."24 Holistic Tao is therefore complemented by individualistic Te. The whole is not an end in itself.

In Zhuangzi's view, Tao is naturally and directly (due to its Power) accessible through the individual (every open-minded one), which is a kind of universal, internal, and innate human agency. ${ }^{25}$ It has also been claimed that "[a] more radical line of thought took each individual as having its own unique xing ['natural tendencies'], a view rooted in parts of the Zhuangzi and developed later by Guo Xiang (?-312 CE)." ${ }^{\prime 26}$ In addition, as Keqian Xu explains, Master Zhuang believed that there are two different selves: "The first is the original and innate self, which is as free, open, and spontaneous as the Dao itself; the other is the socially constructed self, which is fixed, closed, and constrained by his or her worldly existence. What should be forgotten and lost is the latter, not the former"27. However, this is neither Western possessive individualism nor egotism, which are often blamed for environmental, moral, and social degradation. On the one hand, according to Witold Kwaśnicki, Zhuangzi was a supporter of the subjective theory of economic value ${ }^{28}$ (which is linked to free-marketism). On the other hand, according to Xu, Zhuangzian individualism should not be criticized by socialists (because it is different from the pro-capitalist individualism of the West). ${ }^{29}$

\section{Radical Yangist Individualism}

Yang Zhu (Yang Chu, also known as Yangzi) is considered by many to be proto-Taoist, or even an early Taoist belonging to the first phase of this system of

\footnotetext{
${ }^{23}$ See E. Brindley, Individualism in Early China: Human Agency and the Self in Thought and Politics, Honolulu 2010, pp. xxviii-xxx.

${ }^{24}$ K. Lai, "Conceptual Foundations for Environmental Ethics: A Daoist Perspective," Environmental Ethics 25 (2003), p. 247. See also Y. Feng, op. cit., pp. 122-124.

${ }^{25}$ E. Brindley, "Individualism in Classical Chinese Thought," [in:] Internet Encyclopedia of Philosophy, https://www.iep.utm.edu/ind-chin/ (accessed: 19.06.2019), Chapter 6.

${ }^{26}$ F. Perkins, "Metaphysics in Chinese Philosophy," [in:] The Stanford Encyclopedia of Philosophy, E. Zalta (ed.), Winter 2016 Edition, https://plato.stanford.edu/archives/win2016/entries/chinese-metaphysics/ (accessed: 19.06.2019), Chapter 4. See also Zhuangzi, Chapter 8. For example: "What I call perfection of hearing is not hearing others but oneself. What I call perfection of vision is not seeing others but oneself" (Zhuangzi, Chuang Tzu, p. 95).

${ }^{27}$ K. Xu, op. cit., p. 458. See also Y. Zhao, op. cit., p. 176.

${ }^{28}$ See W. Kwaśnicki, Historia myśli liberalnej [History of liberal thought], https://kwasnicki.prawo. uni.wroc.pl/todownload/HMLKwasnicki.pdf (accessed: 24.07.2019), p. 15.

${ }^{29}$ See K. Xu, op. cit., p. 460.
} 
thought (according to Feng Youlan), as he was an important Chinese philosopher who influenced Zhuangzi (even though some of the Yangist ideas were clearly rejected by Zhuangzi ${ }^{30}$. It is generally believed that Yang Zhu did not care about the existence of a state, fate, and afterlife; instead, he had faith ${ }^{31}$ in self-determination and intellect, he also had a secular and liberal attitude in life ("live and let live"). Yang Zhu is traditionally depicted as an egoist in China (and thus condemned); however, as Brindley sums it up:

[...] it seems fair to call him an individualist rather than an apologist for selfish egoism. After all, there is no convincing evidence that Yang Zhu promoted selfishness in the sense that he inspired individuals to seek self-profit through the exploitation of public resources or goods. [...] Rather, most of the reliable evidence points to the fact that Yang Zhu redefined what it meant to value the self in terms of one's personal, material-spiritual salvation. Indeed, Yang Zhu was perhaps one of the first thinkers [...] to see $x$ ing [human nature] and the self as a primary source of idealized individual agency and meaning. ${ }^{32}$

In short, Yang Zhu was probably a revolutionary philosopher who rooted morality into xing and perceived the self as an entity independent from any groups. ${ }^{33}$ Thus, it is perhaps the most radical individualism within Taoism and even Chinese philosophy in general. It should be noted that, according to the thinker, focusing on externals (riches, fame, honor, etc.) and being tied to material things lead to the ignorance of one's internal self, the loss of one's true nature, suffering in reality, and an unhappy life. ${ }^{34}$ As life is precious, Yang Zhu wanted to allow everyone to be happy. The world without both unnatural sacrifices (such as dying for nation and state) and excessive ties to external burdens (such as loving money and power) would be at peace. It is the Taoist view that conformity and greed do lead to the loss of individual nature. Despite some similarities between Yangist and Western individualism, the Yangist self is substantially Taoist (holistic and embodied), as opposed to the Western self (usually atomistic and disembodied, which may result in materialism with outward seeking and the lack of inwardness) ${ }^{35}$. In particular, Taoists do not reduce society to a mere collection of atomized individuals pursuing their own self-interests.

All things considered, in Taoist worldview nature (not culture) is preferred. It must be emphasized that, contrary to the conservative view, the natural order in most cases is different from prevailing social conventions. ${ }^{36}$ Both Yang Zhu and Zhuangzi encouraged people to abandon the socialized external (artificial) self in

30 See W. Wilowski, "Mądrość bezużyteczności Zhuangzi" [The wisdom of uselessness by Zhuangzi], Przeglad Religioznawczy 249 (2013), p. 28; Y. Feng, op. cit., pp. 69-77; J. Rapp, op. cit., pp. 6, 24-25, 28; Ch. Hansen, "Daoism," [in:] The Stanford Encyclopedia of Philosophy, E. Zalta (ed.), Spring 2017 Edition, https://plato.stanford.edu/archives/spr2017/entries/daoism/ (accessed: 19.06.2019), Chapter 3.

31 Throughout this paper, Yang Zhu's ideas are reconstructed, so they should not be understood as definitive claims. In addition, although different views are also published, I accept the view that Yang Zhu belongs to Taoism (based on the referred publications of Professor Feng and Professor Rapp). See also "The Origins of Daoism: Attitudinal Daoism I: Anarchism" in Ch. Hansen, op. cit.

32 E. Brindley, Individualism in Classical..., Chapter 7.

33 See Y. Zhao, op. cit., pp. 173, 175, 178-179, 186.

${ }^{34}$ Ibid., pp. 174-175.

35 See ibid., pp. 182-184.

36 See, for example, E. Nelson, op. cit., p. 310. 
order to return to the true internal (natural) self. Furthermore, "respecting de [Te] entails that the individual cannot simply be sacrificed for the whole." 37 Therefore, individual freedom is very important.

\section{The Moral Philosophy of Taoism}

First of all, Taoist thinkers not only cherished life but also had a great concern for justice: "A work [Laozi's Daodejing] criticizing the exploitation and oppression of people by their rulers, the decay of ethical responsiveness into an adverse bureaucratic morality, and the unforgiving consequences of war and violence is not suitably described as unethical and nihilistic." ${ }^{38}$ Even Yang Zhu was not a moral nihilist. Moreover, it is noteworthy that early Taoist ethics does not depend on gods. So the epistemological question is: what are the sources of moral knowledge and the methods of acquiring it?

Since Taoist opinion on this matter is rather vague (or perhaps just too multidimensional), there is little known for certain about it. An important part of the answer may be found in inward searching methodology which is, however, very different from mystical (Neo-)Platonism. Thus, the mystical interpretation of the Laozi (Daodejing, Tao Te Ching) is most probably flawed. ${ }^{39}$

A deeper understanding is accessible mainly through emptying our "心." It is essential to recognize that the Chinese character 心 (xin) stands for "heart-mind," which should be empty, i.e. freed from excessive thoughts and emotions. ${ }^{40}$ Taoist philosophers distrusted our attachment to thoughts and emotional attitudes, at least to some degree, because they are often instilled and influenced by others. Everyone has the potential to acquire moral knowledge from one's inner experience of Tao (through a meditative life, as Tao can fill the empty heart-mind), and then one can choose to act morally. ${ }^{41}$ It is impossible to fully express such personal experience linguistically because every language is limited and reflects social conventions. Regular and proper meditation is effortless and may bring freedom from distractions (over-thinking, polarized thinking, over-analyzing, being overemotional, prejudices, ${ }^{42}$ etc.). A somewhat similar European concept is Stoic apatheia (equanimity).

According to Zhuangzi, the worst distractions come from the opinionated mind (cheng xin), "believing one's own parochial standard of right and wrong to be uni-

37 Ibid., p. 308.

${ }^{38}$ Ibid., pp. 303-304.

${ }^{39}$ See R. Mazur, Czy "Daodejing" Laozi daje podstawy do interpretacji mistycznej?, https://depot. ceon.pl/bitstream/handle/123456789/3134/Mazur_Rafał.pdf (accessed: 19.06.2019).

40 See J. Iwanowska, op. cit., pp. 24-30, 42.

41 See Y. Huang, "Respecting Different Ways of Life: A Daoist Ethics of Virtue in the 'Zhuangzi,"” Journal of Asian Studies 69 (2010), pp. 1062, 1064.

42 Prejudice is artificial, it is not natural or inborn; prejudice is taught and imposed on individuals by socialization. It blocks our spontaneous attunement to Tao through Te and wu wei. As will be shown below, the main Taoist virtue embodies such an attunement. 
versal," and imposing it on others. ${ }^{43}$ Hence, cheng xin may lead to an authoritarian personality. ${ }^{44}$ In addition, the perceptions of most people are determined by their particular social environment because their minds are fully filled with externals we depend too much on (authoritarian ${ }^{45}$ anti-intraception). In order to get rid of the opinionated mind, Master Zhuang promoted meditation ("to sit and forget," "to fast the mind-heart," etc.), i.e. the process of removing our preconceived opinions (prejudices), and he also encouraged us to imagine possibilities through the use of poetry (it is widely accepted that the Zhuangzi is a literary masterpiece), ${ }^{46}$ paradox, and parable (yuyan). These methods were intended to free the minds of men, since Zhuangzi revealed - often in a humorous way - that overdependence on socialized reason and language leads to the fixed mind of dogmatism. It should be noted that Master Zhuang advocated mild skepticism as he believed that no single point of view is the complete truth. He was the first Chinese philosopher who realized the limitations of human knowledge ${ }^{47}$ due to knowledge being limitless and human lives being finite. Thus, there is no ideal observer who can authoritatively impose his all-embracing standpoint on others and claim that it is the only objective and reasonable one.

Taoist ethics is simple, there are neither hundreds of commandments nor elaborate justifications. Unlike Xunzi and the Legalists (Fajia), Taoists believed that inborn human nature is good (anthropological optimism), ${ }^{48}$ and the original mind is "like a mirror without dust" (reflecting things without prejudices, without cheng xin) ${ }^{49}$ Moreover, Taoist ethics is a kind of non-reductive naturalistic ethics. ${ }^{50}$ The true morality derives from true internal nature ${ }^{51}$ (when living in harmony with external nature). Right actions are Tao-following, whereas morally wrong actions are Tao-abandoning. In addition, as has been suggested by Yang Zhu (according to Yanxia Zhao), "[a]ny so called 'moral principle,' no matter whatever name it is given, if it is a source of painful human vexation, should be not regarded as a true morality, but false morality. [...] this is because only the true virtues can bring peace and true happiness to the people."52 Similarly, according to Zhuangzi: "For just as a duck's legs, though short, cannot be lengthened without pain to the duck, and a crane's legs, though long, cannot be shortened without misery to the crane,

\footnotetext{
${ }^{43}$ Ibid., pp. 1060, 1062.

${ }^{44}$ I borrow this term from Erich Fromm, Theodor W. Adorno, and The Authoritarian Personality (1950).

45 Anti-libertarian.

${ }^{46}$ Although I acknowledge that some parts of the Zhuangzi (the book) were most probably not written by Zhuangzi or even his disciples (particularly Chapters 13, 28, and 33), it is reasonable to posit the reliability of most other parts of the book, including the cited excerpts.

47 X. Liu, op. cit., p. 55.

48 See, for example, Y. Feng, op. cit., p. 186.

${ }^{49}$ Y. Huang, "Respect for Differences: The Daoist Virtue," [in:] The Routledge Companion to Virtue Ethics, L. Besser-Jones, M. Slote (eds.), New York 2015, pp. 105-109.

50 E. Nelson, op. cit., p. 294.

${ }^{51}$ See, for example, Zhuangzi, The Complete Works..., Chapter 8 ("My definition of expertness [...] means following the true form of your inborn nature, that is all").

${ }^{52}$ Y. Zhao, op. cit., p. 181. This is Zhao's interpretation of the ancient philosopher.
} 
so that which is long in man's moral nature cannot be cut off, nor that which is short be lengthened. All sorrow is thus avoided."53 Therefore, significantly bad consequences apparently indicate that good human nature is violated.

From this perspective, Zhuangzi understood that evil and the opinionated mind are widespread in societies in the real world. The reason is an unnatural social environment we are conditioned by. The hope is that our natures can be repaired and our Te can be restored - in other words, we can become broad-minded with unoccupied minds. ${ }^{54}$ Our minds, like muscles, require training (i.e. meditation), which is the major part of moral cultivation that we need.

It is noteworthy that Taoist ethics is likely to be beyond (or between) prevalent altruism and egoism. Unlike altruistic ethics (e.g. Auguste Comte's positivism), Taoism is not based on the principle of preferring others to oneself. One reason is that altruism may justify harming (oneself and others) because it focuses not on how to live individual life, but on how to sacrifice it (as Yang Zhu warned). Nonetheless, unlike egoistic ethics (e.g. Ayn Rand's objectivism), Taoism does not promote the principle of preferring oneself to others. Thus, between moral agents the mutualistic ethics of reciprocity, which recommends treating two sides (oneself and others) equally, is most probably the reasonable ethics between both extremes.

Thinking about deaths caused by altruism and egoism, Master Zhuang commented: "Their deaths were not the same, but the injury to their lives and natures was in each case the same. How then can we applaud the former and blame the latter?"55 Since each individual life is valuable, causing every intentional death is bad, in every form (military aggression, suicide, murder, self-immolation, etc.) and with every motive (fame due to self-sacrifice, material gain, etc.). For this reason, contrary to the popular belief that widespread sacrifice is the most desirable situation, the Taoist philosopher admired the situation in which no great altruism is needed because of the lack of - largely man-made and avoidable - deadly crises and absolute poverty (as shown through the image of the fish left stranded on the ground in comparison with the fish in rivers and lakes, in Chapters 6 and 14 of the Zhuangzi). ${ }^{56}$

53 Zhuangzi, Chuang Tzu, p. 93. "In the highest Daoist standard, everything has its original nature, so a duck's legs should not be lengthened, and a crane's legs should not be cut off; the same for human nature, which should not be modified [...]" (X. Liu, Y. Wong, "Three Groups of the Outer and Miscellaneous Chapters," [in:] Dao Companion to Daoist Philosophy, X. Liu (ed.), Dordrecht 2015, p. 230). See also Zhuangzi, The Complete Works..., Chapter 8 ("What is long by nature needs no cutting off; what is short by nature needs no stretching. That would be no way to get rid of worry. I wonder, then, if benevolence [Confucian ren] and righteousness [Confucian yi] are part of man's true form? Those benevolent men-how much worrying they do!").

${ }^{54}$ See Y. Huang, "Respect...," p. 108.

${ }^{55}$ Zhuangzi, Chuang Tzu, pp. 94-95. See also Zhuangzi, The Complete Works..., Chapter 8 ("Po Yi [the altruist] died for reputation at the foot of Shou-yang mountain; Robber Chih [the egoist] died for gain on top of Eastern Mound. The two of them died different deaths, but in destroying their lives and blighting their inborn nature they were equal. Why then must we say that Po Yi was right and Robber Chih wrong?").

${ }^{56}$ See, for example, Zhuangzi, Chuang Tzu, p. 148. "When the pond dries up, and the fishes are left upon dry ground, to moisten them with the breath or to damp them with spittle is not to be compared with leaving them in the first instance in their native rivers and lakes" (ibid., p. 75). Cf. Zhuangzi, The 


\section{Laozian Ethics and Libertarian Ethical Principles}

The first outline of Taoist ethics was found in the Laozi. According to this book, we should do good acts honestly, spontaneously, with neither pretense nor needing to be noticed. The philosopher criticized deceitfulness, hypocrisy, and traditional Confucian morality, ${ }^{57}$ showing its perversion, corruption, and ongoing degeneration (true virtue is being replaced by conformist, superficial, and enforced ritual). ${ }^{58}$ The medicine prescribed by Laozi" is " $\mathrm{t}$ ]he highest form of goodness [which] is like water [shui 水]." 60 Just like formless water does not impose its shape on any vessels, people should not impose their detailed conception of the good life on others who are all different. However, one should remember that being like water does not mean having victim mentality or being powerless to overcome evil: "Nothing in the world is softer and weaker than water; But, for attacking the hard and strong, there is nothing like it!"61 Water is typically calm, patient, and flexible, so it seems to be weak, whereas it has the real potential to prevail over evil. ${ }^{62}$

In particular, Laozi introduced the group of virtues known as the "three treasures" (sanbao): (1) compassion or love; (2) moderation or frugality; and (3) humility or modesty. ${ }^{63}$ In connection with this, it is worth pointing out that the greatest evil is covetousness of those in power, which leads to wars. ${ }^{64}$ In addition, according to Laozi, robbing and stealing are primarily caused by authorities highly valuing goods that are hard to get, admiring cunning practices, and multiplying laws as well as ordinances (in other words, multiplying human punishments and miseries). ${ }^{65}$ As a result, evil is linked to power relations and no organization has a privileged moral position, so political power needs to be minimized on the basis of some radical ethical standards.

An ethical principle which can be observed in the Laozi (and the Zhuangzi) is non-aggression or non-harming, ${ }^{66}$ and it is related to wu wei (i.e. non-coer-

Complete Works... Water symbolizes Tao. As is indicated in this paper, every loss of Tao is man-made and leads to serious problems in the world.

57 See, for example, S. Palmquist, "A Daoist Model for a Kantian Church," Comparative Philosophy 4 (2013), p. 83; Y. Feng, op. cit., pp. 116-117.

58 See Laozi, Tao Teh..., Chapters 18 and 38.

${ }^{59} \mathrm{I}$ accept the long-established view that Laozi (the Taoist philosopher) existed and his thoughts are contained in the Laozi (the text). For the discussion of postmodern doubts about the authorship and textual formation of the Laozi, see L. Kohn, op. cit., pp. 24-27. Cf. J. Rapp, op. cit., pp. 71-87.

${ }^{60}$ Laozi, Tao Teh..., Chapter 8.

${ }^{61}$ Ibid., Chapter 78. Cf. Laozi, Tao Te..., Chapter 78.

62 Taoist formlessness influenced two famous military strategists: Sun Bin and Sun Tzu.

${ }^{63}$ See Daodejing, Chapter 67.

${ }^{64}$ Laozi, Tao Teh..., Chapter 46 ("When the world has become Taoless, War horses breed themselves on the suburbs. There is no calamity like not knowing what is enough. There is no evil like covetousness").

${ }^{65}$ Ibid., Chapters 3, 19, 57. For example: "The more articulate the laws and ordinances, The more robbers and thieves arise" (ibid., Chapter 57).

66 See ibid., Chapters 60 and 81 ("the Sage himself does no harm to his people. If only the ruler and his people would refrain from harming each other, all the benefits of life would accumulate in the kingdom [but the word 'kingdom' is not found in most translations]" and "The Way of Heaven [The Tao of nature] is to benefit, not to harm"). Cf. Laozi, Tao Te..., Chapters 60, 81 ("the sage also will not 
cive action). Hence, it is similar to both Ahimsa (highly valued in Jainism and Buddhism) and libertarian ethical principles, such as the non-aggression principle (hereafter NAP) and the harm principle. The Taoist ethical principle, just as Ahimsa, arguably applies not only to humans and, although it is understood mainly as "do no physical harm," it can also mean "do no psychological harm." However, Taoist philosophers, as distinct from Mahatma Gandhi and Leo Tolstoy (famous proponents of nonviolence), permitted proportionate self-defense or necessary defense of others (it must not be an enjoyable revenge). The early Taoists extended non-aggression deeply into the political sphere and they condemned mainly the initiation of physical force against others, so their principle has some features of the NAP. This is best exemplified in the following quotes: "You must never think of conquering others by force" 67 and "Only on necessity will he [Taoist] resort to them [to weapons]. For peace and quiet are dearest to his heart, and to him even a victory is no cause for rejoicing. To rejoice over a victory is to rejoice over the slaughter of men!" 68 Laozi believed that war can be neither holy nor good, although purely defensive one should be permissible (antimilitarism). Every largescale rejection of Tao brings bad consequences sooner or later, so, for instance, it may result in the tragedy of war. ${ }^{69}$ Hence, justice is ultimately beneficial.

The above-mentioned basic moral norms are universal and they apply to people equally (even to members of the state apparatus); therefore, when behaving toward others in a moral way, we must not rely on our personal likes and dislikes (impartiality). ${ }^{70}$ Taoism differs from traditional morality which controls people by means of fear, enormous guilt, supernatural punishments and rewards, so in other words conventions organizing hierarchical and authoritarian social relations. Taoist ethical thinking challenged the mainstream cultural tradition (conventional norms and values), ${ }^{71}$ so it was radical and thus mistakenly seen by conformists as "unethical" or "amoral." Laozi and Zhuangzi denounced strictly codified morality and self-righteous moralizing as the unnecessary pollution of internal human nature, the symptom of severe moral degradation of society (and not the cure for it), the loss of spontaneous and genuine good-doing (the loss of Tao and Te), and the means to feel superior to others while making them feel inferior. The Taoists were not morally indifferent by criticizing as unnatural the mainstream Confu-

harm people. When both do not harm each other, Virtue will be accumulated in both for the benefit (of the people)" and "The Way of Heaven [tian zhi dao] is to benefit others and not to injure [= not to harm]"). See also ibid., Chapter 35 ("Hold fast to the great form (Tao), And all the world will come. They come and will encounter no harm; But enjoy comfort, peace, and health").

${ }^{67}$ Laozi, Tao Teh..., Chapter 30. See also Laozi, Tao Te..., Chapter 30 ("He who assists the ruler with Tao does not dominate the world with force").

${ }^{68}$ Laozi, Tao Teh..., Chapter 31. See also Laozi, Tao Te..., Chapter 31 ("Weapons are instruments of evil, not the instruments of a good ruler. When he uses them unavoidably, he regards calm restraint as the best principle. Even when he is victorious, he does not regard it as praiseworthy. For to praise victory is to delight in the slaughter of men").

${ }^{69}$ See Laozi, Tao Teh..., Chapters 30 and 46.

${ }^{70}$ See ibid., Chapters 5 and 79. See also J. Iwanowska, op. cit., p. 36; Ch. Hansen, op. cit., Chapter 3.

${ }^{71}$ See, for example, K. Lai, Conceptual Foundations..., p. 250 ("The Daodejing is incisive in its criticism of contemporary values and virtues in the ancient Chinese context"). 
cian-Legalist values ${ }^{72}$; it can be observed that they avoided the instrumental use of morality as well as such treatment of others. ${ }^{73}$

\section{Zhuangzian Virtue Ethics ${ }^{74}$}

Perhaps the most radical conclusions in an increasingly global village, where the emancipation of minorities (with the individual being the smallest minority on earth) is seemingly promoted, can be drawn from Zhuangzi's focus on the equality (equal value) of differences embodied in each individual (but not the equality of theories created by them). As noted above, equal does not mean identical or interchangeable (individuals are not atoms). Thus, every person has a different inherent nature ( $T e$ or xing). Yong Huang demonstrates a unique form of virtue ethics present in the Zhuangzi which highlights equal respect for others' diverse natural tendencies (an ethics of difference) and which entails that we generally must not impose our own values on others, either out of good or ill will, because such imposition is immoral, as this was metaphorically summarized in the second chapter, "The Equality of Things," in which Zhuangzi asks: "If a human being sleeps in a damp place, the person will have a pain in his or her loins and some paralysis. Is that true of eels? If a human being lives up in a tree, the person will be frightened and tremble. Is that true of monkeys? Which of the three knows the right place to live?" 75 "Therefore, ancient sages do not require them to have the same talents, nor do they force them to do the same things."76 This can be applied to persons in every society, ${ }^{77}$ since Zhuangzi's language is figurative and he was an individualist.

In contrast to the ethics of duty and consequentialism, "virtue ethics emphasizes the cultivation of the moral disposition of the agent. ${ }^{78}$ "Virtues are thought to

${ }^{72}$ See, for example, K. Xu, op. cit., pp. 454-455.

${ }^{73}$ See J. Iwanowska, op. cit., pp. 36-37.

${ }^{74} \mathrm{I}$ acknowledge that Alasdair MacIntyre has contributed greatly to the recent revival of virtue ethics. Nonetheless, his communitarian virtue ethics is inconsistent with Mengzian and Zhuangzian virtue ethics. Therefore, I will not refer to MacIntyre's theory.

${ }^{75}$ Y. Huang, "Respecting Different Ways...," p. 1057 (including Huang's translation of the excerpts from the Zhuangzi). Cf. Zhuangzi, Chuang Tzu, pp. 43-44.

${ }^{76}$ Y. Huang, "Patient Moral Relativism in the 'Zhuangzi,"” Philosophia 46 (2018), https://www. academia.edu/10472568/_2018d_Patient_Moral_Relativism_in_the_Zhuangzi (accessed: 19.06.2019), p. 3. (it is Yong Huang's translation of the excerpt from the Zhuangzi). See also Zhuangzi, The Complete Works..., Chapter 18 ("Creatures differ because they have different likes and dislikes. Therefore the former sages never required the same ability from all creatures or made them all do the same thing. Names should stop when they have expressed reality, concepts of right should be founded on what is suitable. This is what it means to have command of reason, and good fortune to support you").

77 See, for example, M. Puett, Ch. Gross-Loh, op. cit., p. 161 ("On a metaphorical level, this means seeing the world as a butterfly, a bird, a tiger. On a more immediate level, this means understanding the world from another person's point of view").

${ }^{78}$ Y. Huang, "Respecting Different Ways...," p. 1049. Likewise, according to Mark LeBar: "What is typically thought to differentiate a virtue ethic from other forms of ethics is that it focuses moral concern on the character of the agent, rather than on his or her actions." (M. LeBar, "Virtue Ethics," [in:] Arguments for Liberty, A. Powell, G. Babcock (eds.), Washington (DC) 2016, p. 203). "It is character 
be relatively stable traits of character: the ways we are and others come to know us to be." ${ }^{.79}$ Ancient virtue ethics is nowadays gaining attention. ${ }^{80}$ It is concerned with the character development of a person and the whole of a person's life, rather than with particular decisions or actions. Taoist virtue ethics focuses on the way in which the morally appropriate action should be performed: effortlessly, naturally, joyfully, spontaneously (ziran), and gracefully. ${ }^{81}$ Strict obedience to rules and regulations, caused by the feeling of moral or legal duty, is not virtuous; therefore, it is much better to help each other to be good people than to use punishments and laws to deter wrong actions. Since human nature is not originally virtuous and virtues have to be cultivated, the Zhuangzi emphasizes the need of constant practice for the process of character building. Although not virtuous, human nature is good and everyone can become virtuous (without the need for the hierarchical culture which subjugates individual differences in order to conform to a rigid, conventional pattern). ${ }^{82}$

It is worth pointing out that we should not merely follow our natural inborn tendencies; therefore, a truly moral person can also learn to spontaneously recognize and respect the equal value of the natural tendencies of others (the most admirable trait of character which is the Taoist virtue) ${ }^{83}$ It is premised on the principle that when our actions (or the most significant inactions) affect others or are received by them (such others are our moral patients), we - as moral agents - have to take into account our patients' particular interests, so moral action requires the appropriate knowledge of their uniqueness as the moral appropriateness of our conduct is not determined by moral agents' standard (but our moral patients' standard). However, this is not one-sided in a society, since it should be based on some kind of reciprocity (which is not to be identified with the "eye for an eye" punishment system). As a result, we should respect others and ourselves.

In other words, suppressing anyone's (including one's own) natural uniqueness would be tantamount to abandoning $T e$ (which is endowed by Tao). This is not acting as the virtuous person would act. Without following one's own Te and without allowing others to follow each individual's own $T e$, one cannot live the Tao-following (i.e. good) life. It can be mutual between most persons because all moral agents are also moral patients, in different situations interchangeably (although babies and severely mentally deficient persons can only be moral patients).

What does this mean on a practical level? As Huang explains, the Zhuangzian virtue ethics would certainly endorse, for example, homosexuality and being an atheist (both of them are natural), but it would not tolerate initiating aggression towards others, since:

that matters first, and we explicate the moral significance of actions and states of affairs consequentially" (ibid., p. 205).

${ }^{79}$ M. LeBar, op. cit., p. 203.

80 See, for example, The Routledge Companion to Virtue Ethics (2015), Chapters 1-10 and 34).

${ }^{81}$ This is well expressed in Zhuangzi's "knack stories" and in Csikszentmihalyi's "flow" experience.

${ }^{82}$ See Y. Huang, "Respecting Different Ways...," pp. 1059-1061.

${ }^{83}$ Ibid., pp. 1049, 1059, 1062. 
[...] the crucial difference is that homosexuals and atheists can live their lives with equal respect for those who have ways of life different from their own (at least their ways of life do not necessitate interferences with other ways of life), whereas robbers, professional killers, and slave owners cannot live their ways of life with a recognition of the equal worth of the ways of life of those whom they rob, kill, or enslave. The ethics of difference [...] logically [...] cannot respect any ways of life that do not regard other ways of life as having equal worth, just as a good libertarian who values individual freedom cannot value an individual's freedom to take away another individual's freedom. ${ }^{84}$

Zhuangzi does not want us to esteem everything. His ethics of equal liberty (as seen above) would disapprove of - for example - racism, sexism, ableism, and ageism. It can now be understood that it is immoral to murder (and rape, assault, steal, kidnap, defraud, vandalize, etc.) because it causes harm (according to Laozi) and a murderer (evil-doer) evaluates his or her own life as being much more valuable than that of his or her victim (the same applies to somebody's possessions, individual freedom, etc.) (according to Zhuangzi, although it is not the only possible interpretation ${ }^{85}$ ). Furthermore, the universal moral principle found in the Laozi (i.e. non-harming) is compatible with Zhuangzi's "relativism" as it accepts that moral patients may be harmed by different morally relevant actions (in general, harm is relative to the moral patient's standard of right and wrong).

The benign moral relativism of Zhuangzi is an entirely new type of this philosophical view, which is unseen in Western philosophy, since it is the patient-centered relativism (a kind of moral realism), as opposed to the agent-centered and the appraiser-centered familiar types ${ }^{86}$ As Rapp explains, "the relativism of the Zhuangzi is not that of modern moral or cultural [postmodernist] relativists who might deny the existence of eternal absolutes, but that of skeptics who nevertheless accept the principle of an unknowable dao underlying the unity of the universe, even as they believe that the attempt of 'wise men' to put this unity into practice through objective (coercive) action [an authoritarian method] is doomed to violent failure." ${ }^{87}$ Moreover, it is noteworthy that not only humans are our moral patients as this term applies also to sentient non-human animals. Of course, such statement does not imply that moral agents should treat all moral patients, no matter the species, alike. Nonetheless, it is close to ecology.

The best way to interact with others is "to proceed at two levels at once" (liang xing), in other words, a reciprocal consideration of others, which is closely related to "adaptive judgment" (yin shi) ${ }^{88}$ By following this principle, such as the monkey keeper from Chapter 2 of the Zhuangzi who sought harmony and equilibrium between monkeys' tendencies and his own, we achieve concurrence. ${ }^{89}$ Such concurrence really satisfies both sides, as opposed to compromises which are based on sacrifices and leave both sides partially dissatisfied. Thus, both the autonomy

${ }^{84}$ Ibid., p. 1058

${ }^{85}$ Cf. M. Puett, Ch. Gross-Loh, op. cit., p. 157.

${ }^{86}$ Y. Huang, Patient Moral Relativism..., pp. 1-2, 4-8.

87 J. Rapp, op. cit., p. 52.

${ }^{88}$ See, for example, Ch. Fraser, "'Zhuangzi' and the Heterogeneity of Value," [in:] New Visions of the Zhuangzi, L. Kohn (ed.), St. Petersburg (FL) 2015, pp. 52-53.

${ }^{89}$ See Zhuangzi, Chuang Tzu, p. 39. 
of moral patients and the autonomy of the agent are equally respected, without losing anyone's individual nature. ${ }^{90}$

It should be highlighted that Taoist virtue ethics applies chiefly to individual beings and is related primarily to natural differences (rather than cultural differences or whims). Moreover, Taoism - as distinct from multiculturalism - does not encourage anyone to move to another country, nor does it praise human migration. ${ }^{91}$ Therefore, its tolerance seems to be much more compatible with libertarianism than with postmodernism.

\section{Against the Golden Rule}

The Zhuangzian ethics of difference posits a radical alternative to the mainstream principle of moral conduct called the Golden Rule: "Do unto others what you would have them do unto you." The problem with this is that, since the above-mentioned principle presupposes the uniformity of morally relevant likes and dislikes among moral agents and moral patients (an ethics of commonality), it is coercive and dangerous (possibly authoritarian) in the wrong hands. ${ }^{92}$ For example, the Golden Rule could justify (sado)masochist's attempt to cause physical pain to others who are not (sado)masochists (because he or she would like to be subjected to pain or humiliation by others) or the act of killing others and oneself (which is desired by suicidal fanatics). In contrast, Zhuangzi accepted that what one considers as good for others is often not considered good by these others themselves (beings have different morally relevant likes and dislikes). ${ }^{93}$ This is not just a descriptive claim because it entails a normative claim: "whether an action is morally right or wrong should be ultimately determined by the recipient of this action [the moral patient]." 94 One should carefully infer, as a result of Taoist compassion, based mainly on what is clearly communicated as acceptable by one's moral patient. For instance, it may be morally good to cause pain to the sadomasochist with mutual consent (it will not be perceived by him or her as harmful or aggressive), whereas to do so to other moral patients is morally wrong (harm or aggression). This shows a deep respect for individual liberty and autonomy.

Huang has coined the term "Copper Rule" that summarizes the Taoist innovative ethics (libertarian by nature and ready to be applied in our diverse global world): "Do not do unto others what they would not have us do unto them." 95 This is best exemplified in Chapter 18 of the Zhuangzi:

${ }^{90}$ Y. Huang, "The Ethics of Difference in the 'Zhuangzi," Journal of the American Academy of Religion 78 (2010), pp. 85-86.

${ }^{91}$ See Laozi, Tao Teh..., Chapter 80. See also Laozi, Tao Te..., Chapter 80 ("Let the people value their lives highly and not migrate far").

92 See Y. Huang, "A Copper Rule versus the Golden Rule: A Daoist-Confucian Proposal for Global Ethics," Philosophy East and West 55 (2005), pp. 394-402.

93 Y. Huang, "The Ethics...," pp. 74-75.

94 Ibid., p. 65.

95 Y. Huang, "A Copper Rule...," p. 394. Such a negative formulation is the most consistent with wu wei. 
Of old, when a seabird alighted outside the capital of $\mathrm{Lu}$, the Marquis of $\mathrm{Lu}$ went out to receive it, gave it wine in the temple, and had the Jiushao music played to amuse it, and a bullock slaughtered to feed it. But the bird was dazed and too timid to eat or drink anything. In three days it was dead. This was treating the bird as he [the Marquis] would like to be treated, and not as a bird would like to be treated. Had he treated it as a bird would like to be treated, he would have put it to roost in a deep forest, allowed it to wander over the plain, to swim in a river or lake, to feed upon fish, to fly in formation with others. ${ }^{96}$

It is important to note that the Golden Rule represents the ethics of commonality, whereas the Copper Rule represents the differential ethics of uniqueness whose purpose is to fully protect the equal freedom of all noncoercive individuals to develop their own ways of life. Furthermore, even though the Copper Rule (the rule of virtue ethics) guides Taoists to become virtuous, ${ }^{97}$ the ongoing cultivation of spontaneity (ziran) leads to the oblivion of rules and even morals because: " $[\mathrm{t}]$ o be unconscious of one's feet implies that the shoes are easy [that they fit]. To be unconscious of a waist implies that the girdle is easy [that it fits]. The intelligence being unconscious of positive and negative implies that the heart is at ease." "98 Good and evil still exist but advanced Taoists do not attribute good to their conduct (which is exquisitely good but so of itself), thereby becoming genuinely humble.

Thus, the primordial good is beyond good and evil, and so is the human nature after years of successful moral cultivation, ${ }^{99}$ although one should notice that Zhuangzi and Nietzsche had fundamentally different philosophies. ${ }^{100}$ Since the primordial good (i.e. Tao) is nameless (wu ming) and formless (wu xing), it does not create its antitype (evil) in this world, as distinct from man-made names (ming) and conspicuous good deeds (xing). As a result, the Taoists "acting with an empty heart-mind" (wu wei) do not become attached to names so that these adepts are in complete unity with Tao (but without uniformity). This challenged the instrumental and pro-authoritarian use of morality by Confucians and Mohists. ${ }^{101}$

\section{Conclusions: The Radical Tao of Politics}

For the reasons discussed above, Taoist ethics is incompatible with the states we live in and the governments we live under; they are based on aggression (military

${ }^{96}$ Ibid., p. 404 (it is Yong Huang's translation of the excerpt from the Zhuangzi). See also Zhuangzi, Chuang Tzu, p. 176.

97 Y. Huang, "Respecting Different Ways...," p. 1061. "Hursthouse calls such rules 'v-rules' (rules of virtue ethics). In this sense, the Copper Rule can be regarded as a rule generated by the virtue of respecting the equal value of diverse ways of life. If humans are not naturally virtuous, then there is a need for rules to help humans become virtuous" (ibid.).

98 Zhuangzi, Chuang Tzu, p. 186. Cf. Zhuangzi, The Complete Works..., Chapter 19 ("You forget your feet when the shoes are comfortable. You forget your waist when the belt is comfortable. Understanding forgets right and wrong when the mind is comfortable").

${ }^{99}$ Y. Huang, "Respecting Different Ways...," p. 1066.

100 See K. Xu, op. cit., pp. 459-460.

101 See Ch. Hansen, op. cit. The Taoist reflective, meta-ethical theorizing rejected an actually existing, particular social tao and the homogenizing, authoritarian Confucian-Mohist belief in both special moral authority and in the need to impose a single detailed tao on the whole society. 
drafts, victimless crime laws, extensive regressive taxation, etc.), and the numerous laws they create try to enforce the same standards for all subjected to them, thereby oppressing and hindering the uniqueness of each individual. Moreover, Saul Newman has pointed out that "politics has always to be thought of in relation to ethics [...]." ${ }^{102}$ In short, Taoism calls for a radical change in the political system.

Dorota Sepczyńska has analyzed the history of the use of the terms "libertarianism" and "libertarian," and found that they refer to views which satisfy the following conditions: (1) equal liberty/freedom as a core value (the main condition), (2) emphasizing voluntary association, (3) antimilitarism, (4) anthropological optimism, (5) a skepticism of political authority (anarchism or minimal state), and (6) being anti-establishment. ${ }^{103}$ As is well known, most other authors add another one: (7) individualism. ${ }^{104}$ All things considered, philosophical Taoism satisfies the above conditions. In this sense, as is demonstrated throughout this paper, we may agree with Murray Rothbard that "[t]he Taoists were the world's first libertarians [...]."105

Laozi criticized economic interventionism, for example by stating that "[the Taoist sage-ruler says:] I do not engage myself in anything, and the people grow rich. I have no desires, and the people return to simplicity," 106 which sounds like laissez-faire of minimal-state libertarianism (minarchism), although he also criticized: ruthless rivalry and undiminished selfishness, very profit-oriented and property-oriented thinking. Hence, it seems unlikely that Laozi would have endorsed capitalist accumulation. Furthermore, he advised leaders to make sure people are not hungry, ${ }^{107}$ he also wanted a much more equal distribution of wealth ${ }^{108}$ if we read Chapter 77 in the context of Chapter 53. ${ }^{109}$ In other words, Laozian views seem to be more coherent with pro-egalitarian left-libertarianism ${ }^{110}$ than with right-wing libertarian capitalism.

102 S. Newman, The Politics of Postanarchism, Edinburgh 2010, p. 10.

103 D. Sepczyńska, op. cit., pp. 6, 140-148.

${ }^{104}$ See, for example, J. Brennan, Libertarianism, New York 2012, p. 51 ("Are libertarians individualists? In one sense of individualism, yes. Libertarians believe each individual human life is important. They do not regard society as an organism with a good of its own, distinct from the good of the individuals who form it. Libertarians reject the view (associated with fascism, certain versions of conservatism, and radical socialism) that individuals should be sacrificed for the benefit of society as a whole").

105 M. Rothbard, Libertarianism in Ancient China, https://mises.org/library/libertarianism-ancient-china (accessed: 19.06.2019).

${ }^{106}$ Laozi, Tao Teh..., Chapter 57. Cf. Laozi, Tao Te..., Chapter 57 ("I engage in no activity and the people of themselves become prosperous. I have no desires and the people of themselves become simple").

${ }^{107}$ Laozi, Tao Teh..., Chapter 3 ("Therefore, the Sage's way of governing begins by [...] Filling the belly with food [...]").

108 See ibid., Chapter 77 ("The Way of Heaven [The Tao of nature; tian zhi dao] diminishes the more-than-enough to supply the less-than-enough. The way of man is different: it takes from the lessthan-enough to swell the more-than-enough. Who except a man of the Tao can put his superabundant riches to the service of the world?"). Cf. Laozi, Tao Te..., Chapter 77.

109 See Laozi, Tao Te..., Chapter 53 ("Food and drinks are enjoyed beyond limit, And wealth and treasures are accumulated in excess. This is robbery and extravagance. This is indeed not Tao (the Way)").

110 See footnote 9. 
As might be expected, anarchism is the most radical and left-wing form of libertarianism, since it "embodies the most radical expression of the principles of liberty and equality, proclaiming their inextricability, as well as showing that they cannot be adequately realised within a statist framework [...]."111 In this regard, it should be remembered that Zhuangzi provided "the fiercest social criticism in ancient China"112 (an anti-establishment attitude), and the Chinese word for "liberation" is jie fang, which is derived from two terms expressing individual freedom and liberty in the Zhuangzi: "xuan jie" and "tian fang."113 In addition, "[t]he WeiJin [circa 220-420 CE] Daoist term wujun [無君] literally means 'without a prince' [...] and is nearly identical in meaning to the Greek an-archos [...]"114. Taoist anarchism is outlined below after a brief summary of Taoist ethics (anti-statism is its logical conclusion).

Libertarian ethics has not previously been considered to include Taoist virtue ethics. ${ }^{115}$ However, the Taoists' rejection of unnatural social hierarchies and imposed uniformity, and their uncompromising condemnation of the moral hypocrisy of the state, had to have political consequences. The Taoist-libertarian virtue ethics helps us to know what traits of character enable a person to live a good life $^{116}$ and what institutions hinder our ability to make good choices (covetous, hierarchical, deindividualizing, and authoritarian institutions). In addition, it includes pro-libertarian moral norms (the Copper Rule, the non-coercive principle / non-harming ${ }^{117}$ ) and highly respected values, such as individuality, liberty/ freedom, equality, life, tolerance, impartiality, and nature. Thus, we should foster individual self-realization; we must not infringe on the equal liberty of others.

It was difficult to notice a coherent radical theory in the early Taoist texts possibly due to their non-Western manner of conveying meanings and the transformation of Taoism into an organized religion (Daojiao) in later times. That is why it is essential to appreciate again the importance of Joseph Needham's study of civilization in China, characterizing Taoism as "scientific, democratic and politically revolutionary." 118 Moreover, Chad Hansen noted that "philosophical Daoism tends toward pluralism [...] political equality and freedom," and "[i]n ancient China, the political implication of this Dao-ism was mainly an opposition to authority, government, coercion [...]." 119 It should be borne in mind that libertarians advocate reducing political power because to rule is to limit the freedom of gov-

111 S. Newman, op. cit., p. 2.

112 K. Xu, op. cit., p. 449.

113 Ibid.

114 J. Rapp, op. cit., p. 5. In ancient China, Yang Zhu's thought was labelled as wujun by Mengzi.

115 See, for example, M. LeBar, op. cit., pp. 203-232.

116 The main trait: respect for different ways of life; three supplementary ones: compassion, moderation, and humility.

117 Ethically, the Copper Rule is tantamount to non-harming viewed in a patient-relativistic perspective. Politically, it would make the initiation of coercion legally unacceptable. All of these norms can be seen as generated by the Taoist virtues.

118 J. Needham, Science and Civilisation in China, Vol. 2: History of Scientific Thought, Cambridge 1956, p. 35.

119 Ch. Hansen, op. cit. 
erned individuals by means of coercion. From the point of view of anarchism, every state also impairs equality due to the inherently statist hierarchy: the governing authorities - the governed masses. Anarchists accept only radical self-government (as a voluntary association). These are the political consequences of early Taoist ethics, which are the most visible in the Zhuangzian school.

Zhuangzi developed the theory of absolute freedom ${ }^{120}$ or "complete liberty" (according to Feng Youlan ${ }^{121}$ ), which entails "letting the people enjoy a pristine freedom" and "radical anarchy based on natural instincts." 122 His book contains a clear expression of Taoist anarchism in Chapter $9^{123}$ (and, to a slightly lesser extent, in Chapters 8, 10, 11A, and 29 ${ }^{124}$ ). "It indicates that certain revolutionary elements tried to break the conventional constraints [...] on individual natures and contest the cultural confinement imposed by Confucian tradition." 125 The Taoist philosopher believed in spontaneous order because he observed the self-organizing spontaneity of nature (ziran); in addition, people are predisposed to goodness. Hence, the Zhuangzi says that:

There has been such a thing as letting mankind alone; there has never been such a thing as governing [zhi] mankind. (With success.) Letting alone springs from fear lest men's natural dispositions be perverted and their virtue left aside. But if their natural dispositions be not perverted nor their virtue laid aside, what room is there left for government? ${ }^{126}$

Indeed, Taoist political thought evolved from the political apathy of Yang Zhu ${ }^{127}$ and the "left-minarchism" of Laozi into the philosophical individualist anarchism of Zhuangzi and the political communitarian anarchism of the Wei-Jin Taoists (greatly influenced by Master Zhuang) such as Ruan Ji (210-263 CE) and Bao Jingyan (circa $300 \mathrm{CE}) .{ }^{128}$ The stateless anarchist society was expected to safeguard individual liberty and everyone's chances of natural self-fulfillment to the maximum degree possible. ${ }^{129}$ Such a society would be the one most condu-

${ }^{120}$ Y. Zhao, op. cit., p. 179. According to Yanxia Zhao, Zhuangzi inherited the liberty idea from Yang Zhu.

${ }^{121}$ See X. Guo, The Ideal Chinese Political Leader: A Historical and Cultural Perspective, Westport 2002, p. 91; Y. Feng, op. cit., p. 186.

${ }^{122}$ X. Guo, op. cit., p. 92.

${ }^{123}$ See J. Rapp, op. cit., pp. 221-223; Zhuangzi, The Complete Works..., Chapter 9. This chapter rejects the idea of governing $[z h i]$ on the grounds that it is unnatural. It also favors the radical equality of a stateless past.

124 See X. Liu, Y. Wong, op. cit., pp. 228-229.

125 Ibid., p. 232.

126 Zhuangzi, Chuang Tzu, p. 106. Cf. Zhuangzi, The Complete Works..., Chapter 11 ("I have heard of letting the world be, of leaving it alone; I have never heard of governing the world. You let it be for fear of corrupting the inborn nature of the world; you leave it alone for fear of distracting the Virtue of the world. If the nature of the world is not corrupted, if the Virtue of the world is not distracted, why should there be any governing of the world?").

127 See X. Guo, op. cit., p. 99. See also Y. Feng, op. cit., pp. 69-77.

128 J. Rapp, op. cit., pp. 35, 37, 45. See also J. Needham, op. cit., pp. 434-436.

${ }^{129}$ When Tao was valued, "all creatures found happiness in self-fulfillment," "all born to live out their lives unharmed" (B. Jingyan, "Neither Lord Nor Subject," transl. É. Balazs, [in:] Anarchism: A Documentary History of Libertarian Ideas, Volume One, R. Graham (ed.), Montreal 2005, p. 2). "Cunning has its origin in the use of force that goes against the true nature of things [...]" (ibid.); in 
cive to virtuous living, and Zhuangzi cared about a virtuous - apparently "left-libertarian"-character. ${ }^{130}$

First, as John Rapp sums it up, "Ruan's poem ["The Biography of Master Great Man"] clearly contains an anarchist theory of the state." "131 Second, the Taoist philosopher Bao Jingyan (Pao Ching-yen) extended Zhuangzian libertarianism avant la lettre to its logical conclusion, since for him it was not just a theoretical idea. ${ }^{132}$ Third, in terms of political goals, the Taoist concept of $p u$ (as in the phrase $f u p u$ ) may denote the return to the administrative simplicity of prehistoric stateless societies without ruling classes ("rather than acquire an empty reputation for integrity by resigning office and foregoing one's salary, it is better that there should be no office to resign. [...] In the earliest times, there was neither lord nor subjects. [...] everyone was free and at ease; neither competing with each other nor scheming against each other"133), thereby changing rulers back into leaders. ${ }^{134}$ Furthermore, it is very possible that mythological rulers of China were simply tribal leaders. ${ }^{135}$ Therefore, all things considered, the radical Tao undermines political authority.

\section{Bibliography}

Brennan J., Libertarianism, New York 2012.

Brindley E., "Individualism in Classical Chinese Thought," [in:] Internet Encyclopedia of Philosophy, https://www.iep.utm.edu/ind-chin/ (accessed: 19.06.2019).

Brindley E., Individualism in Early China: Human Agency and the Self in Thought and Politics, Honolulu 2010.

Feng Y., Krótka historia filozofii chinskiej [A short history of Chinese philosophy], transl. M. Zagrodzki, Warszawa 2001.

Fraser Ch., "'Zhuangzi' and the Heterogeneity of Value," [in:] New Visions of the Zhuangzi, L. Kohn (ed.), St. Petersburg (FL) 2015, pp. 40-58.

the earliest times, "people did not appropriate each other's property" and "did not attack one another" (ibid.); "Their hearts being pure, they were devoid of cunning" (ibid., p. 3); "How, then, could there have been accumulation of property such as to rob the people of their wealth, or severe punishments to trap and ensnare them?" (ibid.).

${ }^{130}$ Looking back, one should remember that both Yang Zhu and Laozi helped to lay the foundations for the Zhuangzian virtue ethics.

131 J. Rapp, op. cit., p. 36.

132 See ibid., pp. 37-40.

133 B. Jingyan, op. cit., p. 2. "The Way and its Virtue ( Tao te) having fallen into decay, a hierarchy was established. Customary regulations for promotion and degradation and for profit and loss proliferated [...]" (ibid., p. 3); "Daily they became further removed from the ways of their ancestors, and turned their back more and more upon man's original simplicity" (ibid.); "As soon as the relationship between lord and subject is established, hearts become daily more filled with evil designs [...]" (ibid., pp. 3-4).

${ }^{134}$ See also, for example, J. Rapp, op. cit., pp. 77-78 ("even the received DDJ [Laozi's Dao De Jing] is trying to subvert government by advising the ruler to emulate leaders of hunter-gatherer bands and thus remove the ruler's monopoly on the legitimate use of coercion - advice that would do away with the state as it is minimally defined by Max Weber").

135 See B. Smolik, "Kulturowe uwarunkowania przywództwa politycznego w Chinach kontynentalnych-przykład konfucjanizmu," Wrocławskie Studia Politologiczne 12 (2011), p. 231. 
Guo X., The Ideal Chinese Political Leader: A Historical and Cultural Perspective, Westport 2002.

Hansen Ch., "Daoism," [in:] The Stanford Encyclopedia of Philosophy, E. Zalta (ed.), Spring 2017 Edition, https://plato.stanford.edu/archives/spr2017/entries/daoism/ (accessed: 19.06.2019).

Huang Y., "A Copper Rule versus the Golden Rule: A Daoist-Confucian Proposal for Global Ethics," Philosophy East and West 55 (2005), pp. 394-425.

Huang Y., "The Ethics of Difference in the 'Zhuangzi," Journal of the American Academy of Religion 78 (2010), pp. 65-99.

Huang Y., "How to Do Chinese Philosophy in a Western Philosophical Context: Introducing a Unique Approach to Chinese Philosophy," Hanxue Yanjiu (Chinese Studies) 31 (2013), pp. 117-151.

Huang Y., "Patient Moral Relativism in the 'Zhuangzi,'" Philosophia 46 (2018), https://www.academia.edu/10472568/_2018d_Patient_Moral_Relativism_in_ the Zhuangzi (accessed: 19.06.2019).

Huang Y., "Respect for Differences: The Daoist Virtue," [in:] The Routledge Companion to Virtue Ethics, L. Besser-Jones, M. Slote (eds.), New York 2015, pp. 99-112.

Huang Y., "Respecting Different Ways of Life: A Daoist Ethics of Virtue in the 'Zhuangzi,'" Journal of Asian Studies 69 (2010), pp. 1049-1069.

Iwanowska J., "Can a Daoist Sage Have Close Relationships with Other Human Beings?," Diametros - An Online Journal of Philosophy 52 (2017), pp. 23-46.

Jingyan B., "Neither Lord Nor Subject," transl. É. Balazs, [in:] Anarchism: A Documentary History of Libertarian Ideas, Volume One, R. Graham (ed.), Montreal 2005, pp. 1-4.

Kohn L., Taoizm. Wprowadzenie [Introducing Daoism], transl. J. Hunia, Kraków 2012. Kwaśnicki W., Historia myśli liberalnej [History of liberal thought], https://kwasnicki. prawo.uni.wroc.pl/todownload/HMLKwasnicki.pdf (accessed: 24.07.2019).

Lai K., "Conceptual Foundations for Environmental Ethics: A Daoist Perspective," Environmental Ethics 25 (2003), pp. 247-266.

Lai K., "The 'Daodejing': Resources for Contemporary Feminist Thinking," Journal of Chinese Philosophy 27 (2000), pp. 131-153.

Laozi, Tao Teh Ching, transl. J.C.H. Wu, New York 1961, https://terebess.hu/english/ tao/wu.html (accessed: 19.06.2019).

Laozi, Tao Te Ching, transl. W.-T. Chan, https://terebess.hu/english/tao/chan.html (accessed: 19.06.2019).

LeBar M., "Virtue Ethics," [in:] Arguments for Liberty, A. Powell, G. Babcock (eds.), Washington (DC) 2016, pp. 203-232.

Liu J., Wprowadzenie do filozofii chińskiej. Od myśli starożytnej do chińskiego buddyzmu [An introduction to Chinese philosophy: From ancient philosophy to Chinese Buddhism], transl. M. Godyń, Kraków 2010.

Liu X., "Daoism: Laozi and Zhuangzi," [in:] The Oxford Handbook of World Philosophy, W. Edelglass, J. Garfield (eds.), Oxford 2011, pp. 47-57.

Liu X., Wong Y., "Three Groups of the Outer and Miscellaneous Chapters," [in:] Dao Companion to Daoist Philosophy, X. Liu (ed.), Dordrecht 2015, pp. 221-237. 
Mazur R., Czy "Daodejing" Laozi daje podstawy do interpretacji mistycznej?, https://depot. ceon.pl/bitstream/handle/123456789/3134/Mazur_Rafał.pdf (accessed: 19.06.2019).

Needham J., Science and Civilisation in China, Vol. 2: History of Scientific Thought, Cambridge 1956.

Nelson E., "Responding with 'Dao': Early Daoist Ethics and the Environment," Philosophy East and West 59 (2009), pp. 294-316.

Newman S., The Politics of Postanarchism, Edinburgh 2010.

Nisbett R., The Geography of Thought: How Asians and Westerners Think Differently... and Why, New York 2003.

Palmquist S., "A Daoist Model for a Kantian Church," Comparative Philosophy 4 (2013), pp. $67-89$.

Perkins F., "Metaphysics in Chinese Philosophy," [in:] The Stanford Encyclopedia of Philosophy, E. Zalta (ed.), Winter 2016 Edition, https://plato.stanford.edu/archives/win2016/entries/chinese-metaphysics/ (accessed: 19.06.2019).

Puett M., Gross-Loh Ch., The Path: What Chinese Philosophers Can Teach Us About the Good Life, New York 2017.

Rapp J., Daoism and Anarchism: Critiques of State Autonomy in Ancient and Modern China, New York 2012.

Rothbard M., Libertarianism in Ancient China, https://mises.org/library/libertarianism-ancient-china (accessed: 19.06.2019).

Schwartz B., Starożytna myśl chińska [The world of thought in ancient China], transl. M. Komorowska, Kraków 2009.

Schwitzgebel E., "Zhuangzi's Attitude Toward Language and His Skepticism," [in:] Essays on Skepticism, Relativism, and Ethics in 'the Zhuangzi,' P. Kjellberg, P. Ivanhoe (eds.), Albany (NY) 1996, pp. 68-96.

Sepczyńska D., Libertarianizm. Mało znane dzieje pojęcia zakończone próba definicji [Libertarianism. Little-known history of the concept that ends with an attempt to define it], Olsztyn 2013.

Smolik B., "Kulturowe uwarunkowania przywództwa politycznego w Chinach kontynentalnych — przykład konfucjanizmu," Wrocławskie Studia Politologiczne 12 (2011), pp. 227-247.

Wilowski W., "Mądrość bezużyteczności Zhuangzi" [The wisdom of uselessness by Zhuangzi], Przeglad Religioznawczy 249 (2013), pp. 27-44.

Wong D., "Chinese Ethics," [in:] The Stanford Encyclopedia of Philosophy, E. Zalta (ed.), Fall 2018 Edition, https://plato.stanford.edu/archives/fall2018/entries/ethics-chinese/ (accessed: 3.07.2019).

Xu K., "A Different Type of Individualism in 'Zhuangzi," Dao: A Journal of Comparative Philosophy 10 (2011), pp. 445-462.

Zhao Y., "Yang Zhu's 'Guiji' Yangsheng and Its Modern Relevance," Philosophy Study 4 (2014), pp. 173-188.

Zhuangzi, The Complete Works of Chuang Tzu, transl. B. Watson, New York 1968, https://terebess.hu/english/chuangtzu.html (accessed: 19.06.2019).

Zhuangzi, Chuang Tzu, transl. H. Giles, [sine loco] 2013.

Zhuangzi, Zhuangzi. Prawdziwa ksiega południowego kwiatu, transl. M. Jacoby, Warszawa 2009. 


\section{ERRATA}

\begin{tabular}{c|c|c}
\hline Strona & Jest & Powinno być \\
\hline 107 & harming, and people & harming, and uniforming people
\end{tabular}

„Studia Philosophica Wratislaviensia” vol. XIV, fasc. 4 (2019)

Studia Philosophica Wratislaviensia vol. XIV, fasc. 4 (2019) () for this edition by CNS 